\title{
Adaptation resources in subjects with social and psychosomatic disadaptation: A comparative analysis
}

\author{
Olga S. Deyneka ${ }^{a^{*}}$, Elena R. Isaeva ${ }^{\mathrm{b}}$ \\ ${ }^{a}$ Department of Political Psychology, St. Petersburg State University, St. Petersburg, Russia \\ b Chair of General and Clinical Psychology, St. Petersburg State Medical University, \\ St. Petersburg, Russia
}

*Corresponding author. E-mail: osdeyneka@yandex.ru

\begin{abstract}
In the context of changing socio-economic conditions, it is very important to study the mechanisms of human adaptation and disadaptation. Coping strategies and psychological defense mechanisms, combined with the value system, were considered adaptive resources. Human response to uncertainty, stress or the frustrating factors of the social environment involves different levels, and consequences could be canalized in different ways. To carry out a comparative study of adaptive resources in patients with essential hypertension (psychosomatic disadaptation) and the unemployed (social disadaptation). To diagnose defense mechanisms, the LSI questionnaire by Plutchik, Kellerman \& Conte was administered to the subjects. To study coping behavior, Lazarus's WCQ method was used. To assess values, an authorial technique by Deyneka was used. There were two study groups and one control group. In total, there were 165 subjects in the study (55 in each group). The mean age was 42.6 years, and there were $40 \%$ men and $60 \%$ women. In the unemployed group, defensive and coping behavior was characterized by excessive use of escape-avoidance and high levels of repression of traumatizing information, and in psychosomatic patients with essential hypertension there was excessive use of the coping style "accepting responsibility". Specificity of the problem areas of value systems in the two groups was found. Essential hypertension patients are characterized by problems in family relationships and by intrapsychic problems (horizontal conflicts). The unemployed are burdened with conflicts in the systems "employee-management", "citizen-state", and "individual-the world" (vertical conflicts). These results could be helpful for specialists in helping professions in their attempts to find reasons and problematic areas of individual's disadaptations at different levels.
\end{abstract}

Keywords: adaptation resources, defense, coping, value system, disadaptation, unemployed, psychosomatic patients 


\section{Introduction}

In contemporary Russian society, individuals' lives and health have become more valuable due to the significant decrease in manpower. The society and the state are interested in supporting the basic resource of the population in its psychological and somatic health. In the context of changing socio-economic conditions, it is very important to study the mechanisms of human adaptation and disadaptation.

Psychological adaptation is a complex phenomenon that refers either to shortterm adjustments, such as behavioral reactions, to a longer process such as adaptation state, or to an integral dynamic characteristic of personality that reflects the capacity to adjust to drastic changes of the environment (Deyneka, 1999). Disadaptation is defined as a decrease in an individual's capacity to adjust to a changing environment or to stressful situations. It might last for some time and result in various negative consequences. Prolonged disadaptation leads to unproductive attitudes, increased anxiety and social conflicts. Deficiency in either biological (somatic) or social adaptation is projected at the level of personality, or the psychological level, since personality is understood as a sustainable integration of psychic qualities and processes with various external manifestations.

Human response to uncertainty, stress or frustrating factors of the social environment involves different levels, and consequences could be canalized in different ways. Dealing with stress affects an individual's body and can result in deteriorated health, and/or it can cause disadaptation manifested in disrupted relationships. For instance, the complex socio-psychic phenomenon of unemployment, which is socio-economic in nature, should be viewed not only at macro- and micro-social levels but also at the personal and even psychosomatic levels. There is a convincing study (Demin, 2004) suggesting that the psychological effects of unemployment involve different levels. However, psychosomatic and personal levels have rarely been combined in studies of unemployment, where such research is vital due to a high risk of psychosomatic disorders among the unemployed (Hanisch, 1999).

Conversely, analysis of psychosomatic disorders might be misleading if they do not take into consideration the socio-psychological context. Disadaptive behavior of individuals with psychosomatic disorders could be caused by their psychological reactions to different levels of conflict (intrapsychic, interpersonal or socio-economic), as well as by conflict of values, due to which some of the individual's needs are frustrated rather than satisfied. Values are dynamic constellations formed by society and determined by its characteristics; they could be understood as an individual's adaptation potential (Deyneka, 1999; 2002) or adaptation resource.

Thus, it is advisable to explore common and specific characteristics of disadaptation at different levels via analysis of adaptation mechanisms and values as dynamic personal constellations.

In Russian the literature, there are stable interests in psychological defense mechanisms and mechanisms of coping. They are understood as the most important forms of an individual adaptation processes (Karvasarsky, 1990; Ancyferova, 1994; Sirota, 1994; Isaeva, 1999, 2010; Granovskaya \& Nikolskaya, 2001; Ababkov \& Perrez, 2004; Bogdanova \& Dotsenko, 2010; Sokolova, 2011, etc.).

Coping strategies can be defined as mechanisms mediating between a stressful event and reaction; they are expressed in cognitive, emotional and behavioral areas 
and determine individual's adaptation to the current situation (Lazarus, 1966; Folkman \& Lazarus, 1988). A resource-based approach (Billings \& Moos, 1981), especially the conservation of resources (COR) theory to understanding coping, seems particularly promising (Hobfoll, 1988). Coping resources include the individual's resources (self-concept, internal control locus, cognition resources, affiliation, empathy, and attitudes towards life, death, love, faith, spirituality and value- motivational structure of personality) and the resources of the social environment (the environment in which a person lives, as well as his ability to find, receive and provide social support).

Defense mechanisms (DMs) are among the most important components of adaptation. They arise developmentally earlier, are more sustainable than coping mechanisms and are based on typological qualities and emotional dynamic patterns of personality (Wasserman et. al. 1998; Isaeva, 2010, Plutchik, Kellerman, \& Conte, 1979). DMs should be understood as perceptive, intellectual and motile automatic unconscious patterns acquiring different levels of complexity and developing in the process of involuntary and voluntary learning (Freud, 1993). DMs are automatically triggered in situations of conflict, frustration and stress. Their function is to decrease emotional tension until the situation changes. A set of defense mechanisms is specific for each individual, and it characterizes his or her level of adaptation.

Thus, DMs and coping strategies are significant and interconnected mechanisms of psychological adaptation; they blend together to form a lasting construct of "defensive and coping behavior", which determines the efficiency of an individual's interaction with their environment. Conversely, it should be taken into consideration that disadaptation, like psychosomatic disorder, influences an individual's behavior and attitudes. Disease changes a patient's relationships with the environment, as well as his or her behavior, emotions and cognitive processes. A number of diseases might lead to a significant change in the personal value system. Disease can change an individual's relationships, prospects and long-term outlook.

Defensive and coping behaviors should be viewed from the perspective of an individual's inner world and, primarily, from a perspective of their value system (Antsyferova, 1994; Korostyleva, 2004). Values are the core of any culture; they are concentrated spiritual expressions of different social groups' needs and interests (Zdravomyslov, 1986). They are pivotal factors in voluntary regulation of individual behavior and activity. Attitudes can be understood as external manifestations of values.

We have attempted to combine personality-oriented and comparative approaches in order to study adaptation resources and specifics of defensive and coping styles in people with somatic and social disadaptation. The novelty and scientific significance of the study is that coping strategies, defense mechanisms and values are explored at two levels: social and psychosomatic adaptations. The main goal of the study was to carry out comparative analysis of attitudes and adaptation mechanisms in subjects with psychosomatic and social disadaptation.

\section{Method}

There were two study groups and one control group. In total, there were 165 subjects in the study ( 55 per group). The mean age was $42.6 \pm 3.9$ years, consisting of $40 \%$ men and $60 \%$ women. The groups were balanced for sex and age. The first 
group consisted of subjects with psychosomatic disadaptation (in particular, essential hypertension (EH), stages I and II). The second group consisted of individuals undergoing an employment crisis (unemployed), that is, with social disadaptation. The control group consisted of state company (Military Topography Institute) employees who provided a baseline for both study groups. Control group members had been undergoing regular medical assessments and can be considered relatively healthy compared to members of the $\mathrm{EH}$ group. In contrast to the unemployed group, the controls had high socio-economic status, social protection and guaranteed salary.

The methods of study consisted of two parts: 1) techniques for the study of adaptation mechanisms (coping strategies and psychic defenses) and 2) techniques for the study of values and attitudes.

To diagnose psychic defense mechanisms, the Life Style Index questionnaire (LSI, Plutchik, Kellerman, \& Conte, 1979) was administered to the subjects. This questionnaire consists of 97 statements that describe feelings or actions, to which the subject agrees or disagrees. This technique was tested and normalized in the V.M. Bekhterev Institute (Wasserman et al., 2005).

To study coping behavior, R. Lazarus's Ways of Coping Questionnaire (WCQ) was used. This method was tested in the V.M. Bekhterev Psychoneurologic Institute and adapted by scientists from different research teams (Kryukova, Kuftyak, 2005; Wasserman et al, 2009). The questionnaire consists of 50 behavioral responses to difficult situations and a four-point response scale. Standard variants of behavior in difficult situations were united in 8 scales (obtained by factor analysis): planful problem solving, positive reappraisal, accepting responsibility, seeking social support, confrontation, self-control, distancing, and escape-avoidance.

To explore the value system, a method invented by O. Deyneka was employed, in which subjects were asked to arrange their attitudes by their significance (the first list) and by the degree of anxiety they cause (the second list). That is, the first list aims to reveal prioritized values, while the second one provides information about problematic areas in the value system. There were 14 items in each list. The value system is understood as an integral system of an individual's selective voluntary attitudes to different aspects of reality (Myasischev, 2003). The questionnaire covered attitudes that might produce conflicts at different levels: intrapsychic (attitude to self), interpersonal at the level of family (parents, children, spouse), organization (colleagues, management), country (state) and at the global level. In addition, it included attitudes to two polar types of exchange resources, love and money, and to their dichotomies, death and creativity.

\section{Results}

This study showed that the main coping strategies for all groups are planful problem solving and positive reappraisal (see Table 1). This suggests that most subjects, regardless of health and social status, use active problem-focused coping strategies to deal with life challenges. In general, middle-aged people tend to use cognitive coping strategies to reappraise and devalue traumatic (frustrating) events by keeping a positive outlook or searching for a "deeper meaning" of the event. 
Table 1. Coping behavior in the study groups (descriptive statistics)

\begin{tabular}{lcccccc}
\hline \multirow{2}{*}{ Coping strategy } & \multicolumn{2}{c}{ Control } & \multicolumn{2}{c}{$\begin{array}{c}\text { Psychosomatic } \\
\text { disadaptation } \\
\text { (EH patients) }\end{array}$} & \multicolumn{2}{c}{$\begin{array}{c}\text { Social } \\
\text { disadaptation } \\
\text { (unemployed) }\end{array}$} \\
\cline { 2 - 7 } & $\mathbf{M}$ & $\boldsymbol{\sigma}$ & $\mathbf{M}$ & $\boldsymbol{\sigma}$ & $\mathbf{M}$ & $\mathbf{\sigma}$ \\
\hline Confrontation & 54.1 & 15.3 & 53.1 & 21.2 & 55.4 & 19.1 \\
Distancing & 47.1 & 12.9 & 46.8 & 20.1 & 51.3 & 18.6 \\
Self-control & 59.5 & 16.5 & 58.4 & 16.7 & 63.8 & 14.7 \\
Seeking social support & 54.6 & 17.9 & 55.9 & 21.1 & 58.2 & 16.7 \\
Accepting responsibility & 52.4 & 23.8 & $68.6^{* * *}$ & 17.9 & 61.6 & 21.2 \\
Escape-avoidance & 43.6 & 20.8 & 42.6 & 18.2 & 62.1 \\
Planful problem solving & 67.5 & 17.4 & 68.6 & 19.1 & 67.2 & 18.9 \\
Positive reappraisal & 64.8 & 18.9 & 63.4 & 18.9 & 69.6 & 18.7 \\
\hline
\end{tabular}

Note. In this Table, as well as in Tables $2-4$, the number of asterisks $\left(^{*}\right)$ indicates significance of difference (Van der Waender criteria): ${ }^{*}$ for $p<.05$; ${ }^{* *}$ for $p<.01$; and ${ }^{* *}$ for $p<.001$ (in comparison with control group).

In the EH patients group, in contrast to the control group, the coping strategy of accepting responsibility is used much more frequently $(p<.001)$. In the unemployed group the coping strategy of escape-avoidance is used more frequently than in the other two groups, and the difference is statistically significant $(p<.001)$. In most situations, escape-avoidance is an unproductive and disadaptive way of dealing with life challenges. As this study has shown, the escape-avoidance strategy is specific to the unemployed group.

Analysis of psychological defense mechanisms showed that denial is one of the main defense mechanisms in the control group, that is, the group of relatively healthy people with a job (see Table 2).

Table 2. Psychological defense mechanisms in the study groups

\begin{tabular}{lcccccc}
\hline \multirow{2}{*}{$\begin{array}{c}\text { Psychic defense } \\
\text { mechanism }\end{array}$} & \multicolumn{2}{c}{ Control } & \multicolumn{2}{c}{$\begin{array}{c}\text { Psychosomatic } \\
\text { disadaptation } \\
\text { (EH patients) }\end{array}$} & \multicolumn{2}{c}{$\begin{array}{c}\text { Social } \\
\text { disadaptation } \\
\text { (unemployed) }\end{array}$} \\
\cline { 2 - 7 } & $\mathbf{M}$ & $\mathbf{\sigma}$ & $\mathbf{M}$ & $\mathbf{\sigma}$ & $\mathbf{M}$ & $\mathbf{\sigma}$ \\
\hline Denial & 66.5 & 26.3 & $42.5^{* * *}$ & 26.4 & 67.9 & 23.8 \\
Repression & 51.7 & 27.4 & $42.7^{*}$ & 27.8 & $71.0^{* *}$ & 23.5 \\
Regression & 56.8 & 29.1 & 53.9 & 29.2 & 58.1 & 28.5 \\
Compensation & 59.5 & 28.7 & $44.2^{* *}$ & 27.2 & $41.5^{* * *}$ & 27.1 \\
Projection & 47.4 & 23.0 & $38.0^{* * *}$ & 27.1 & $29.0^{* * *}$ & 28.4 \\
Displacement & 59.8 & 24.1 & $34.6^{* * *}$ & 23.5 & $37.5^{* * *}$ & 23.0 \\
Intellectualization & 53.6 & 23.5 & $33.0^{* * *}$ & 24.6 & $32.6^{* * *}$ & 24.6 \\
Reaction formation & 49.3 & 26.8 & 55.7 & 27.9 & 60.3 & 31.5 \\
\hline
\end{tabular}


In the EH patients group, most defense mechanisms are significantly below the baseline $(p<.05)$, i.e., significantly different from the control group. This implies that these individuals' defense systems are too weak to resist daily hassles, making them vulnerable to stressful situations. In the unemployed group, the main defense mechanism is repression $(p<.05)$. The other predominant psychic defense is denial (at the level of baseline). Reaction formation in the unemployed group is higher than that in the control group $(p<.01)$. Such mechanisms as compensation, intellectualization, projection and splitting are significantly lower in the unemployed group than in the control group $(p<.001)$.

Table 3. Values rank in the control group and in the $\mathrm{EH}$ patients group (descriptive statistics and ranks)

\begin{tabular}{|c|c|c|c|c|c|c|}
\hline \multirow{2}{*}{ Areas of life } & \multicolumn{3}{|c|}{ Control group } & \multicolumn{3}{|c|}{$\begin{array}{c}\text { Psychosomatic } \\
\text { disadaptation group }\end{array}$} \\
\hline & Rank & $\mathbf{M}$ & $\sigma$ & Rank & M & $\sigma$ \\
\hline \multicolumn{7}{|l|}{ Important areas } \\
\hline Attitude to situation in the country & 9 & 8.2 & 3.6 & 5 & $5.3^{* * *}$ & 2.7 \\
\hline Attitude to children & 8 & 7.8 & 3.9 & $3 / 4$ & $4.2^{\star * *}$ & 2.8 \\
\hline Attitude to management & 11 & 9.1 & 3.1 & 10 & 10.1 & 1.9 \\
\hline Attitude to situation in the world & 12 & 9.8 & 2.7 & 12 & 10.5 & 2.6 \\
\hline Attitude to religion & 10 & 8.9 & 3.7 & 11 & 10.1 & 2.9 \\
\hline Attitude to love & 2 & 3.9 & 2.4 & 6 & $5.7^{\star * *}$ & 2.4 \\
\hline Attitude to money & 7 & 7.6 & 3.2 & 9 & $9.5^{\star \star}$ & 2.4 \\
\hline Attitude to self & 3 & 5.1 & 3.3 & $3 / 4$ & 4.2 & 2.4 \\
\hline Attitude to colleagues & 6 & 7.5 & 2.6 & 7 & 8.0 & 2.5 \\
\hline Attitude to parents & 1 & 1.8 & 1.7 & 1 & $2.5^{\star \star}$ & 1.7 \\
\hline Attitude to freedom & $4 / 5$ & 6.7 & 3.4 & 8 & $9.2^{* * *}$ & 3.1 \\
\hline Attitude to death & 14 & 11.4 & 3.5 & 14 & 11.7 & 2.5 \\
\hline Attitude to spouse (partner) & $4 / 5$ & 6.7 & 3.4 & 2 & $2.7^{* * *}$ & 2.3 \\
\hline Attitude to creativity & 13 & 10.1 & 3.5 & 13 & 10.7 & 3.1 \\
\hline \multicolumn{7}{|l|}{ Anxiety-ridden areas } \\
\hline Attitude to situation in the country & 4 & 6.4 & 3.9 & 5 & 5.3 & 3.3 \\
\hline Attitude to children & 10 & 8.7 & 3.6 & 4 & $4.7^{\star \star \star *}$ & 2.7 \\
\hline Attitude to management & 11 & 8.8 & 3.5 & 9 & 9.6 & 2.1 \\
\hline Attitude to situation in the world & 8 & 7.8 & 3.8 & 13 & $10.5^{\star * *}$ & 2.3 \\
\hline Attitude to religion & 13 & 9.2 & 3.7 & 8 & 8.5 & 3.6 \\
\hline Attitude to love & 2 & 5.0 & 3.2 & 6 & $5.9^{\star *}$ & 3.1 \\
\hline Attitude to money & 7 & 7.8 & 3.3 & 7 & 8.3 & 3.2 \\
\hline Attitude to self & 5 & 6.5 & 3.8 & 3 & $4.3^{\star *}$ & 2.7 \\
\hline Attitude to colleagues & 9 & 8.3 & 3.3 & 10 & $9.6^{*}$ & 2.8 \\
\hline Attitude to parents & 1 & 3.6 & 3.6 & 1 & 3.0 & 2.7 \\
\hline Attitude to freedom & 3 & 6.4 & 3.9 & 11 & $9.7^{* * *}$ & 2.9 \\
\hline Attitude to death & 12 & 9.1 & 4.1 & 12 & 10.3 & 3.6 \\
\hline Attitude to spouse (partner) & 6 & 6.6 & 3.1 & 2 & $3.5^{\star * *}$ & 3.2 \\
\hline Attitude to creativity & 14 & 10.8 & 3.3 & 14 & 10.7 & 3.1 \\
\hline
\end{tabular}

Note: More important or anxiety-ridden areas are ranked with smaller numbers. 
Table 4. Values rank in the control group and in the unemployed group

\begin{tabular}{|c|c|c|c|c|c|c|}
\hline \multirow{2}{*}{ Areas of life } & \multicolumn{3}{|c|}{ Control group } & \multicolumn{3}{|c|}{ Social disadaptation group } \\
\hline & Rank & $\mathbf{M}$ & $\sigma$ & Rank & $\mathbf{M}$ & $\sigma$ \\
\hline \multicolumn{7}{|l|}{ Important areas } \\
\hline Attitude to situation in the country & 9 & 8.2 & 3.6 & 3 & $4.1^{\star * *}$ & 3.3 \\
\hline Attitude to children & 8 & 7.8 & 3.9 & 2 & $3.7^{* * *}$ & 2.5 \\
\hline Attitude to management & 11 & 9.1 & 3.1 & 8 & $7.6^{*}$ & 3.5 \\
\hline Attitude to situation in the world & 12 & 9.8 & 2.7 & 11 & 10.0 & 2.7 \\
\hline Attitude to religion & 10 & 8.9 & 3.7 & 12 & 10.1 & 2.6 \\
\hline Attitude to love & 2 & 3.9 & 2.4 & 4 & $4.8^{*}$ & 2.3 \\
\hline Attitude to money & 7 & 7.6 & 3.2 & 5 & $5.6^{\star *}$ & 3.1 \\
\hline Attitude to self & 3 & 5.1 & 3.3 & 6 & $7.3^{* * *}$ & 3.2 \\
\hline Attitude to colleagues & 6 & 7.5 & 2.6 & 9 & $9.2^{* *}$ & 3.1 \\
\hline Attitude to parents & 1 & 1.8 & 1.7 & 1 & 2.4 & 1.7 \\
\hline Attitude to freedom & $4 / 5$ & 6.7 & 3.4 & 10 & $9.4^{* * *}$ & 2.8 \\
\hline Attitude to death & 14 & 11.4 & 3.5 & 14 & 12.4 & 2.3 \\
\hline Attitude to spouse (partner) & $4 / 5$ & 6.7 & 3.4 & 7 & 7.4 & 3.7 \\
\hline Attitude to creativity & 13 & 10.1 & 3.5 & 13 & 10.5 & 2.5 \\
\hline \multicolumn{7}{|l|}{ Anxiety-ridden areas } \\
\hline Attitude to situation in the country & 4 & 6.4 & 3.9 & 3 & 5.2 & 4.1 \\
\hline Attitude to children & 10 & 8.7 & 3.6 & 2 & $5.0^{* * *}$ & 3.5 \\
\hline Attitude to management & 11 & 8.8 & 3.5 & 10 & 8.9 & 2.8 \\
\hline Attitude to situation in the world & 8 & 7.8 & 3.8 & 12 & 9.3 & 2.8 \\
\hline Attitude to religion & 13 & 9.2 & 3.7 & 6 & $7.5^{*}$ & 3.9 \\
\hline Attitude to love & 2 & 5.0 & 3.2 & 4 & 5.9 & 2.9 \\
\hline Attitude to money & 7 & 7.8 & 3.3 & 7 & 7.6 & 2.5 \\
\hline Attitude to self & 5 & 6.5 & 3.8 & 9 & 8.1 & 4.4 \\
\hline Attitude to colleagues & 9 & 8.3 & 3.3 & 5 & 7.1 & 3.5 \\
\hline Attitude to parents & 1 & 3.6 & 3.6 & 1 & 2.7 & 2.3 \\
\hline Attitude to freedom & 3 & 6.4 & 3.9 & 11 & $8.9^{* *}$ & 3.3 \\
\hline Attitude to death & 12 & 9.1 & 4.1 & 13 & 9.8 & 4.2 \\
\hline Attitude to spouse (partner) & 6 & 6.6 & 3.1 & 8 & 7.7 & 3.8 \\
\hline Attitude to creativity & 14 & 10.8 & 3.3 & 14 & 11.3 & 2.4 \\
\hline
\end{tabular}

Since coping strategies are connected to certain kinds of attitudes individuals have towards the world, our task included studying the subjects' values by studying their attitudes to different aspects of micro-society. In addition to designating the most important areas of the subjects' lives, anxiety-ridden areas were revealed. In Tables 3 and 4, we rank the important and anxiety-ridden areas within the study groups.

The most important, as well as the most anxiety-ridden area (rank 1) for all groups, is attitude to parents. The average age of our respondents is approximately forty years (midlife crisis), and considering their parents' ages and deteriorating health, attitude to parents appears to be a relevant issue. Elderly parents not only 
activate a feeling of responsibility in their children, but these grown-up children also approach the final stage of their own lives, coming to understand that they remain someone's children only while their parents are alive. An individual is unconditionally valued by his or her parents and will always be unique for them. Thus, attitude to parents can be an adaptation resource during midlife crisis.

The other important and anxiety-ridden area for the control group is the respondents' attitude to love. Many of those who undergo a midlife crisis try to find an adaptation resource in love as a source of youth and inspiration. The area of attitude to self is also ranked as highly important.

In the control group, important areas and anxiety-ridden areas overlap to a lesser degree than in the groups with social or psychosomatic disadaptation. This might indicate the relative well-being of the control group individuals in many areas that could be controlled by them.

In the EH patients group, the most important areas, in addition to attitude to parents, are attitude to spouse (partner), attitude to self, attitude to children and attitude to situation in the country. In comparison to the control group, attitude to spouse (partner), attitude to children and attitude to situation in the country are more important for EH patients to a statistically significant degree (see Table 3 ). Since the number of married patients (or those having a relationship with a partner in any form of civil marriage) and the number of those having children was approximately the same in both groups, a comparison is acceptable. For EH patients, such areas as attitude to spouse (partner), attitude to self and attitude to children are significantly more ridden with frustration, anxiety and tension.

In the unemployed group, the most important areas are attitude to parents, attitude to children, attitude to situation in the country and attitude to love. Attitude to money is also important to them. For the unemployed group, such areas as attitude to situation in the country, attitude to children and attitude to money are statistically significantly more important than for the control group. Anxiety-ridden areas that are statistically significant for the unemployed group are attitude to children and to lesser degree, attitude to freedom.

Statistically significant differences between EH patients and unemployed subjects allow us to clarify specificity of problematic areas in their values. For psychosomatic patients, such areas as attitude to spouse (partner) and attitude to self are much more important $(p<.001)$ and anxiety-ridden $(p<.001)$. In the unemployed group, attitude to management $(p<.001)$, attitude to situation in the country $(p<.05)$, attitude to money $(p<.001)$ and attitude to love $(p<.05)$ are most important. For unemployed subjects, more anxiety is provoked by such areas as attitude to colleagues $(p<.001)$ and attitude to situation in the world $(p<.05)$.

Correlation analysis (Spearman rank correlation) of data obtained in each test group was performed separately.

In the group of psychosomatic patients, the following relationship between the characteristics of the value-semantic sphere and the characteristics of a person's adaptive resources has been established.

For individuals often using "confrontation" coping, the attitude to freedom turned out to be significant $(\mathrm{r}=.29 ; p<.05)$ as well as frustrating $(\mathrm{r}=.29 ; p<.05)$, and they also manifested a low level of concern and anxiety in relation to religion $(\mathrm{r}=.29 ; p<.05)$. 
The higher the rating of freedom for an individual in the hierarchy of values is, the worse he bears the requirements of the external environment and social setting. Such people tend to consider many aspects of life as unjust, violations of their rights, and infringement on their freedom, and they strive directly and unambiguously to claim these freedoms.

It should be noted that in most cases, confrontation is not a constructive way of resolving problems. Confrontational behavior reflects a strengthening of activity, often impulsive and inconsistent, with the purpose of trying to influence the situation. In the emotional sphere, there is a prevalence of asthenic emotions, such as aggression, anger and annoyance. In the cognitive sphere, there is disorganization of mental activity, the absence of a plan of action, affective capture of the situation, excessive straightforwardness in judgment, lack of flexibility and a defensive position. In daily life, such behavior is called "flying off the handle" or "running up to conflict."

For essential hypertension patients, who often turn to distancing, the value of the relationship sphere with their spouse (friend) is lower $(\mathrm{r}=-.27 ; p<.05)$; they are more concerned about the situation in the world $(\mathrm{r}=-.30 ; p<.05)$. The ability to step back from the emotional wave of problems, to switch attention away from the stressor (switch off), probably helps them to leave the conflict zone promptly, through internal (psychological) withdrawal from the object causes stress. Therefore, the subjectively low significance of relationships revealed in the responses of patients with essential hypertension is a strategy of conscious reduction (depreciation) of the importance of any emotional intimacy (emotional withdrawal from relationships causing pain). It should be noted that the tendency to distance themselves in this group negatively correlates with age $(\mathrm{r}=-.28 ; p<.05)$.

The constructive coping type "search of social support" combines in the group of $\mathrm{EH}$ patients with a low level of concern and with no visible problems in the sphere of relationships with children $(r=-.30 ; p<.05)$. Perhaps it is in this area that sick people find the necessary support and understanding. It is noteworthy that for psychosomatic patients actively making use of "search of social support" coping, significant areas of interest are the situation in the world and current events $(\mathrm{r}=.29 ; p<.05)$. Perhaps hypertensive patients take to heart the events, which they cannot influence, maintaining a high level of stress that directly affects their health. Alternatively, the awareness of their own vulnerability (helplessness) due to their illness, relative to possible global changes that could adversely affect the well-being and health of these patients, may shift the importance of the situation in the world to a priority area in the field of subjective values.

This marked strategy of "acceptance of responsibility" coping in overcoming problems in the case of $\mathrm{EH}$ patients is not always constructive, as it is accompanied by increasing feelings of guilt, self-doubt, anxiety and depressive experiences, especially in situations where the circumstances do not depend on the person. However, in individuals with a high level of assuming guilt and responsibility, the anxiety and fear in the monetary and financial spheres of life is much less $(\mathrm{r}=-.44 ; p<.01)$, although they characterize their income as low $(\mathrm{r}=-.38 ; p<.01)$. In addition, they have no concerns about their freedom $(\mathrm{r}=-.41 ; p<.01)$. The high negative correlation of "acceptance of responsibility" coping with concerns about market values (money and freedom), suggests that hypertensive patients, who prefer this type 
of coping, are not directly involved in the society crisis, and soften these issues by presenting increased requirements to themselves.

The correlation analysis has also found that the more the desire for recognition of responsibility in current events and emerging problems is expressed, the more the conflict in relation to love is realized $(\mathrm{r}=.31 ; \mathrm{p}<.05)$, the less significant relationships are with children $(\mathrm{r}=-.27 ; \mathrm{p}<.05)$ and the less significant the relationship is with the boss $(\mathrm{r}=-.30 ; \mathrm{p}<.05)$. At the same time, a very close relationship of "acceptance of responsibility" coping to the "projection" defense has been revealed $(\mathrm{r}=.48 ; \mathrm{p}<.001)$. Perhaps there is a complex of responsible self-sufficiency in hypertensive patients and the projection of this responsibility onto other significant people.

In patients with hypertension, active problem-focused "systematic problem solving" is combined with concern about the situation in the country $(r=.37 ; \mathrm{p}$ $<.01)$. We can assume that $\mathrm{EH}$ patients actively involved in solving problems and overcoming stress factors show concern with the public macro-social field in their value-sense sphere. Here, a kind of transference from the individual level to the level of the state can be found. The coping style is "transmitted" to a higher level in the form of expectations of the state's (as an institution with secured stability functions associated with predictability and prospects in its policy) planning and efficiency, followed by a certain disappointment in the fact that it cannot currently cope with its functions.

In the structure of hypertensive patients' psychological defenses, a correlation with the value-sense sphere of personality has also been found. The largest number of connections with the values attitude and significant spheres of relations of the individuals in this group exist with the "reactive formations" protection mechanism (overcompensation). For hypertensive patients with the dominance of this protection in life priorities and values, the attitude towards oneself $(r=.37 ; p<.01)$ and towards their parents stands out as significant $(\mathrm{r}=.31 ; p<.05)$ and as disturbing $(\mathrm{r}=.31 ; p<.05)$. At the same time, they are frustrated in the sphere of relation to love $(\mathrm{r}=.35 ; p<.05)$, as well as somewhat worried about relation to death $(\mathrm{r}=-.38$; $p<.01$ ). For hypertensive patients, who more often prefer "reaction formations", the significance of the situation in the state is less important $(\mathrm{r}=-.31 ; p<.05)$.

Indeed, they are more focused on themselves and their own problems. In patients with a predominance of this protection, there is little concern for the money sphere $(\mathrm{r}=.27 ; p<.05)$. Consequently, they are less likely to use money as compensation; for them self-realization is more important. These structural connections of a "reaction formations" defense confirm that the less successful the hypertensive patients are in areas such as material success, social utility or recognition, the more they are focused on themselves, often devaluing real life topics, and reorienting them to self-realization.

The "compensation" defense in EH patients showed a moderate connection with the importance of the sphere of relations with the boss $(r=.27 ; p<.05)$. Since the boss acts as a parent figure (especially in the context of the Russian mentality), a positive relationship with the boss is an actualization of the need to defend oneself from an inferiority complex. The connection of the "projection" defense with anxiety in relationships with colleagues is widely present $(\mathrm{r}=.40 ; p<.01)$. This immature defense mechanism may contribute to conflicts in the workplace. Fear and 
anxiety in the love sphere often require the involvement of the "rationalization" mechanism $(\mathrm{r}=-.31 ; p<.05)$.

In the group of socially maladjusted persons, correlation analysis revealed the following features of the connections between the value-motivational sphere of an individual and the characteristics of the adaptive resource in the form of protective and coping styles.

Coping in the form of "escape" is combined with a low significance of the love sphere $(\mathrm{r}=.27 ; p<.05)$. Among the unemployed this strategy of coping is more often used by men than by women $(\mathrm{r}=.27 ; p<.05)$.

Coping using "self-control", on the other hand, proved to be beneficial for those for whom love is a value. For the unemployed who prefer this strategy, the attitude to love is not only significant $(\mathrm{r}=.28 ; p<.05)$ but also a less frustrating $(\mathrm{r}=-.29$; $p<.05)$ sphere.

For the unemployed with a preference for "acceptance of responsibility" coping, the value of the sphere of the relationship with a spouse (friend) is less important $(\mathrm{r}=-.35 ; p<.05)$ and the significance of the sphere of the relationship with the boss is greater $(\mathrm{r}=.28 ; p<.05)$. In addition, they are concerned about the sphere of their relation to creativity $(\mathrm{r}=-.33 ; p<.05)$. It is clear that their unemployed status frustrates them primarily because of the inability to fulfill their potential and to create.

The mechanism of "denial" showed a highly significant correlation with the importance of the sphere of relations with the boss $(\mathrm{r}=.47 ; p<.001)$ as well as significance with the sphere of relations with colleagues $(\mathrm{r}=-.28 ; p<.05)$, but with high anxiety $(\mathrm{r}=.29 ; p<.05)$ in this sphere. The sphere of relations with colleagues is frustrating $(\mathrm{r}=.27 ; p<.05)$ in the case of coping through "distancing." It is probable that among the unemployed there are more of those who do not know how to set up relationships with colleagues in a competitive environment, preferring to deny the potential conflicts in this sphere of life.

"Repression", which is closely associated with projection $(\mathrm{r}=.37 ; p<.01)$, is highly correlated with anxiety in the sphere of relations with children $(r=.37$; $p<.01)$ and moderately correlated with low importance of the situation in the state $(\mathrm{r}=-.33 ; p<.05)$. While repressing the problems of the present-day Russian state, this group is nevertheless anxious for its children and its children's prospects, projecting current misfortunes on the children.

For those unemployed who have shown the "compensation" defense, the love sphere is less important in life $(\mathrm{r}=-.31 ; p<.05)$. The status of the unemployed increases the need to compensate for the deficit in this sphere.

For those unemployed who are more likely to resort to rationalization, the situation in the world was a more significant $(\mathrm{r}=-.34 ; p<.05)$, and more disturbing $(\mathrm{r}=.28 ; p<.05)$ sphere of relations. Indeed, with the negative developments in the world, one's own problems (temporary loss of job, status, and reduction of household income) appear to be less severe. In addition, the unemployed can connect their job crisis with the general negative trends occurring in the world, for example, converting into discourse "the world is collapsing and we are the victims of this collapse."

This substitution mechanism provides a low level of anxiety in relation to death $(\mathrm{r}=.28 ; p<.05)$. It should be noted that for those unemployed for whom the relationship with the spouse (friend) is more meaningful, the situation in the state is 
less important $(\mathrm{r}=-.42 ; p<.01)$. Thus, the data obtained in the study of the valuemotivational sphere of relationships of the unemployed suggest that patients with safer and happier relations in the family, or in love, endure the job crisis more easily.

\section{Discussion}

The following conclusions were made in relation to defensive and coping styles of subjects with disadaptation.

Subjects with psychosomatic disadaptation (EH patients) are characterized by weak ego-defenses, leading to chronic anxiety and tension. EH patients' coping styles tend to be excessively active, restless, blaming themselves, accepting responsibility for most external events and anxiously looking for an opportunity to undo their mistakes. This mode of stress reaction and problem-solving causes increased emotional tension and contributes to the development of somatic disorders. The results of our study do not contradict the data other authors obtained, for example, from patients with varying degrees of severity of hypertension (Fomina, 2013) and from people who have had a myocardial infarction (Biktina, 2015).

Subjects with social disadaptation (unemployed) tend to repress unpleasant or traumatizing information and ignore anxiety-provoking events (as well as thoughts and feelings) to maintain their self-esteem. On the one hand, these tendencies protect psychic integrity and inner balance, but on the other hand, they interfere with adequate assessment of the environment (due to a kind of barrier between what is perceived and what comes into awareness) and with efficient coping behavior aimed at problem solving. The coping behavior of unemployed respondents is characterized by an excessive tendency to avoid problems. This group also tends to underestimate the importance of stressful events or find the positive aspects, allowing maintenance of optimism in most situations. In studies by other authors, nonconstructive coping strategies in unemployed individuals have also been found (for example, Koretskaya, 2012).

Important areas and anxiety-ridden areas overlap for groups with disadaptation (both psychosomatic and social), which means that these important areas are conflict-ridden for them. In addition, EH patients are characterized by predominance of "horizontal" conflicts such as family problems and intrapsychic problems. Individuals with social disadaptation (unemployed) are also affected by "vertical" conflicts in systems "employee - management", "citizen-state", "individual - the world". As underlined by V. Frankl, the unemployed are accused of their plight in all spheres of life (Frankl,1990). Correlation analysis revealed various connections between the specificity of the value system and characteristics of adaptation resources. In general, it is possible to state that unconscious ego-defense mechanisms to a significant degree determine the structure and hierarchy of one's values and attitudes. Second, the choice of behavioral response to a stressful stimulus is based on a hierarchy of personal values. Moreover, adequate conscious coping behavior supports one's structure of the value system. If coping behavior is disadaptive, there will be anxiety-ridden areas in the value system that determine actual or potential conflicts. 


\section{Conclusion}

Comparative analysis of adaptation resources (defensive and coping behaviors and specificity of the value system) in subjects with social and psychosomatic disadaptation leads to the following conclusions. The findings of the study revealed common features as well as specificity of defensive and coping behaviors in the compared groups. Problems relating to the adaptation process in EH patients are manifested in excessive use of the coping strategy accepting responsibility combined with a low level of psychological defense function. This coping strategy is not the best option because its psychological costs are very high. In the unemployed group, defensive and coping behaviors are characterized by excessive use of escape-avoidance and high levels of repression of unpleasant or traumatizing information. This behavior, socially unproductive as it is, could protect individuals and could be considered a preferable short-term solution.

Specifics of problematic areas in the value systems of the compared groups were revealed. EH patients are characterized by problems in family relationships and by intrapsychic problems ("horizontal conflicts"). Individuals with social disadaptation (unemployed) are burdened with conflicts in systems "employee - management", "citizen-state", or "individual - the world" ("vertical conflicts").

The results of correlation analysis have confirmed the connection between the specifics of an individual's inner world (values and attitudes) and defensive and coping behaviors that contribute to adaptation resources. The results of this study could be helpful for specialists in helping professions in their attempts to find reasons for, and problematic areas of, an individual's disadaptation at different levels leading to real or potential conflicts in the internal or external worlds.

\section{References}

Ababkov, V. A., Perrez, M. (2004). Adaptatzija k stress. Osnovy teorii, diagnostiki, terapii [Adaptation to stress. Basic theory, diagnosis, therapy]. St.Petersburg: Rech.

Ancyferova, L. I. (1994). Lichnost v trudnyh zhiznennyh uslovijah: pereosmyslivanie, preobrazovanie situacij i psyhologicheskaja zashhita [The person in difficult life conditions: rethinking, the transformation of situations and psychological defense]. Psihologicheskij zhurnal [Psychological Journal], 15(1), 3-19.

Biktina, N. N. (2015). Smyslozhiznennye orientatzii i koping-strategii bol'nyh, perenesshih infarct miokarda [Meaningfull life attitudes and coping-strategies of patients that experienced myocardial infraction]. Fundamentalniye issledovaniya [Fundamental Research], 2, 411-415.

Billings, A. G., \& Moos, R. H. (1981). The role of coping responses and social resources in attenuating the stress of life events. Journal of Behavioral Medicine, 4(2), 139-157.

Bogdanova, M. V., \& Dotsenko, E. L. (2010). Samoreguljatzija lichnosti: ot zashhit $k$ sozidaniju [Self-regulation of personality: From defenses to creation]. Tyumen, Russia: Mandr\&K.

Deyneka, O. S. (1999). Ekonomicheskaja psyhologia: Socialno-politicheskie problemy [Economic Psychology: Social and political issues]. St.Petersburg: St.Petersburg State University.

Deyneka, O. S. (2002). Ekonomiko-psyhologicheskoe pole osoznanija globalizacionnyh processov v rossijskoj dejstvitelnosti [Economic and psychological field of awareness of globalization processes in the Russian reality]. In V.Ju. Bolshakov (Ed.), Rossiya: planetarnye processy [Russia: planetary processes]. (pp. 265-302). St.Petersburg: St.Petersburg State University. 
Demin, A. N. (2004). Lichnost v krizise zanjatosti [The identity crisis in employment]. Krasnodar, Russia: Kuban State University.

Folkman, S., \& Lazarus, R. (1988). Manual for ways of coping questionnaire. Palo Alto, CA: Consult. Psychol. Press.

Fomina, N. V. (2013). Osobennosti sovladaushhego povedeniya u bolnyh s raznoj stepenju tjazhesti arterialnoj gipertonii [Peculiarities of coping behavior in patients with varying degrees of severity of hypertension. In Kryukova T.L. (Ed.)., Psikhologiya stressa i sovladaniya [Psychology of stress and coping]. Proceedings of the III International scientific-practical conference. (pp. 150-152). Kostroma, Russia: Kostroma State University.

Freud, A. (1966). Ego and the mechanisms of defense. London: Hogarth Press and Institute of Psycho-Analysis. (Original work published 1937)

Granovskaya, R. V. \& Nikolskaya, I. M. (2001). Zashhita lichnosti. Psyhologicheskie mehanismy [Defense of personality. Psychological mechanisms]. St.Petersburg: Znanie.

Hanisch, K. A. (1999). Job loss and unemployment research from 1994 to 1998: A review and recommendations for research and intervention. Journal of Vocation Behavior, 55(2), 188220.

Hobfoll, S. E. (1989). Conservation of resources: A new attempt at conceptualizing stress. American Psychologist, 44(3), 513-524.

Isaeva, E. R. (2010). Sovladajushhee so stressom i zashhitnoe povedenie lichnosti pri rasstrojstvah psyhicheskoj adaptacii razlichnogo geneza [Coping and psychological defense mechanisms of the individual with disorders of mental adaptation of various genesis] (Unpublished doctoral thesis). St.Petersburg State University, St.Petersburg.

Isaeva, E. R., \& Wasserman, L. I. (2004). Zashhitno-sovladajushhij stil i ego rol v psyhologicheskoj adaptacii lichnosti [Coping-defensive style and its role in the psychological adaptation of the personality]. In L.A. Korostyleva (Ed.), Psychologicheskie problemy samorealizacii lichnosti [Psychological issues of the contemporary personality]. Vol. 8. (pp. 206-216). St.-Petersburg: St.-Petersburg State University.

Karvasarskij, B. D. (1990). Nevrozy [Neuroses]. Moscow: Medicina.

Koretskaya, E. V. (2012). Problema samoreguljatzii aktivnosti bezrabotnyh v situatzii poteri raboty. [The problem of self-activity of the unemployed in a situation of unemployment]. Uchenye zapiski. Elektronnyj nauchnyj zhurnal Kurskogo gosudarstvennogo universiteta [The Researchers Notes. Electronic Journal of the Kursk State University], 1. Retrieved from: http:// scientific-notes.ru/pdf/023-036.pdf

Korostyleva, L. A. (2004). Teoretiko-metodologicheskie osnovy psyhologii samorealizacii lichnosti v zhiznedejatelnosti [The theoretical-methodological bases of psychology of personality self-realization in the life]. In L. A. Korostyleva (Ed.), Psyhologicheskie problemy samorealizacii lichnosti [Psychological issues of personality self-realizatoin]. Vol. 8. (pp. 3-24). St.Petersburg: St.Petersburg State University

Kryukova, T. L., \& Kuftyak, E. V. (2005). Oprosnik sposobov sovladanija (adaptacija metodiki WCQ) [Ways of coping questionnaire (adaptation of WCQ method). Psihologicheskaja diagnostika [Psychological diagnostics], 3, 57-76.

Lazarus, R. S. (1966). Psychological stress and the coping process. New York: McGraw-Hill.

Myasishhev, V. N. (2003). Psyhologija otnoshenij [The psychology of relationships]. Moscow, Voronezh: Rech.

Plutchik, R., Kellerman, H., \& Conte, H. (1979). A structural theory of ego defense and emotions. In E. Izard (Ed.), Emotions in personality and psychopathology. New York: Plenum Press. 
Sirota, N. A. (1995). Coping-povedenie v podrostkovom vozraste [Coping-behavior in adolescence]. (Unpublished doctoral thesis). St.Petersburg Bekhterev Psychoneurological Research Institute, St.Petersburg.

Sokolova, E. T. (2011). Phenomenon of psychological defense. Psychology in Russia: State of the Art, 4, 204-225. doi: 10.11621/pir.2011.0012

Wasserman, L. I., Klubova, E. B., \& Eryshev, O.F. (2005). Psyhologicheskaja diagnostika indeksa zhiznennogo stilja: Posobie dlja vrachej i psyhologov [Psychological diagnostics of the index of life style: Manual for physicians and psychologists]. St.-Petersburg: St.Petersburg Bekhterev Psychoneurological Research Institute.

Wasserman, L. I., Iovlev, B. V., Isaeva, E. R., Trifonova, E. A., Shchelkova, O. J., Novozhilova, M. Y., \& Vuks, A. Y. (2009). Metodika dlja psyhologicheskoj diagnostiki sposobov sovladanija so stressom i problemnumi dlja lichnosti situacijami: Posobie dlja vrachej i meditzinskih psyhologov [Methods of psychological diagnosis for ways of coping with stress and problem situations for the person: Manual for doctors and medical psychologists]. St. Petersburg: St. Petersburg Bekhterev Psychoneurological Research Institute.

Zdravomyslov, A. G. (1986). Potrebnosti. Interesy. Cennosti [Needs. Interests. Values]. Moscow: Politizdat. 